Miloš D. Đurić

$81^{\prime} 255.2: 53$

Elektrotehnički fakultet

https://doi.org/10.18485/climb.2017.5.2.ch16

Univerzitet u Beogradu

Nada Krnjaić-Cekić

Mašinski fakultet

Univerzitet u Beogradu

\title{
PREVOĐENJE DISKURSA FIZIKE ELEKTRIČNIH GASNIH PRAŽNJENJA IZ PERSPEKTIVE TEORIJE RELEVANTNOSTI
}

\section{Sažetak}

Naša analiza se zasniva na pretpostavci teorije relevantnosti o ulozi inferencije u razumevanju i kognitivno-semantičkoj distinkciji između konceptualnih i proceduralnih kodiranja. Takođe, ispituemo hipotezu prema kojoj se prevođenje može objasniti kao slučaj demonstrativno-inferencijalne komunikacije. Ovu hipotezu proveravamo u korpusima koji obuhvataju diskurs fizike električnih gasnih pražnjenja (tj. prevod sa engleskog na srpski jezik). Pošto tvrdimo da Teorija relevantnosti obezbeđuje eksplicitan okvir koji može da objasni proces prevođenja, želimo da ilustrujemo izvesne diskrepance u prevodu koje nastaju usled dejstva interpretativne sličnosti između onoga što se kodira i onoga što se saopštava. Analiziramo i objašanjavamo pojavu interpretativne sličnosti kada dve propozicionalne reprezentacije dele svoje analitičke i kontekstualne implikacije u datom kontekstu, kao i naše nalaze o tome da jaz između onoga što se kodira i onoga što se saopštava ima relevantne posledice za prevod. Pored toga, očuvanje originalnog informacionog sadržaja zahteva da eksplikature i implikature dobijenog prevoda treba da budu iste kao i eksplikature i implikature originala. Opazili smo slučajeve kada prevodilac odlučuje da kodira interpretaciju onoga što se nameravalo saopštiti izvornim konceptom. Drugim rečima, ono što se saopštava konceptom može odstupati od onoga što taj koncept kodira pomoću: sužavanja koncepta, oslabljivanja koncepta, odjekivanja koncepta i širenja koncepta. Pored toga, prevodilac ponekada upotrebljava direktni prevod čime obuhvata labaviji stepen vernosti. Uvodimo novo sagledavanje ovog problema primenjujući okvir teorije relevantnosti kao naš analitički aparat za analiziranje prevoda diskursa fizike električnih gasnih pražnjenja sa engleskog na srpski jezik. S jedne strane, verujemo da perspektiva teorije relevantnosti može da ponudi 
prevodiocima važne sastojke da bi shvatili izvesne kognitivne procese koji se koriste da prenesu značenje i intenciju sa jednog na drugi jezik. S druge strane, naše istraživanje bi takođe moglo da doprinese analizi procesa usvajanja drugog jezika, naročito ukoliko se semantička komponenta tog procesa smatra jednosmernim prevodom sa jezika L1 na L2.

Ključne reči: prevodni ekvivalenti, teorija relevantnosti, interpretativna sličnost, labaviji stepen vernosti, engleski jezik, srpski jezik, diskurs fizike električnog gasnog pražnjenja, podaci zasnovani na korpusu.

\subsection{Uvodne napomene}

Oslanjajući se na teorijski okvir teorije relevantnosti, ispitujemo hipotezu prema kojoj se prevođenje može objasniti kao slučaj demonstrativno-inferencijalne komunikacije. Naša analiza se zasniva na pretpostavci teorije relevantnosti o ulozi inferencije u razumevanju i kognitivno-semantičkoj distinkciji između konceptualnih i proceduralnih kodiranja. Našu hipotezu proveravamo u korpusima koji obuhvataju diskurs fizike električnih gasnih pražnjenja (tj. prevod sa engleskog na srpski jezik). Pošto tvrdimo da Teorija relevantnosti obezbeđuje eksplicitan okvir koji može da objasni proces prevođenja, želimo da ilustrujemo izvesne diskrepance u prevodu koje nastaju usled dejstva interpretativne sličnosti između onoga što se kodira i onoga što se saopštava. Analiziramo i objašanjavamo pojavu interpretativne sličnosti kada dve propozicionalne reprezentacije dele svoje analitičke i kontekstualne implikacije u datom kontekstu, kao i naše nalaze o tome da jaz između onoga što se kodira i onoga što se saopštava ima relevantne posledice za prevod. Pored toga, očuvanje originalnog informacionog sadržaja zahteva da eksplikature i implikature dobijenog prevoda treba da budu iste kao i eksplikature i implikature originala. Opazili smo slučajeve kada prevodilac odlučuje da kodira interpretaciju onoga što se nameravalo saopštiti izvornim konceptom. Drugim rečima, ono što se saopštava konceptom može odstupati od onoga što taj koncept kodira pomoću: sužavanja koncepta, oslabljivanja koncepta, odjekivanja koncepta i širenja koncepta. Pored toga, prevodilac ponekada upotrebljava direktni prevod čime obuhvata labaviji stepen vernosti. Uvodimo novo sagledavanje ovog problema primenjujući okvir teorije relevantnosti kao naš analitički aparat za analiziranje prevoda diskur- 
sa fizike električnih gasnih pražnjenja sa engleskog na srpski jezik. S jedne strane, verujemo da perspektiva teorije relevantnosti može da ponudi prevodiocima važne sastojke da bi shvatili izvesne kognitivne procese koji se koriste da prenesu značenje i intenciju sa jednog na drugi jezik. S druge strane, naše istraživanje bi takođe moglo da doprinese analizi procesa usvajanja drugog jezika, naročito ukoliko se semantička komponenta tog procesa smatra jednosmernim prevodom sa jezika L1 na L2. Ovde, svakako, vredi napomenuti I da se prevođenje može posmatrati na dva različita načina. S jedne strane, postoji usko određenje direktnog prevođenja koje je orijentisano ka stimulansu, dok, s druge strane, posotoji jedan širi pojam koji je interpretativno orijentisan, a koji bi se mogao nazvati indirektnim prevodom, po analogiji sa direktnim prevodom (Gutt 1989: 87).

U okviru ovog rada vršiće se ispitivanje na nivou diskursa i biće usmereno na mogućnost primene teorije relevantnosti na prevođenje naučnih tekstova iz oblasti fizike električnih gasnih pražnjenja sa engleskog na srpski jezik. Polazimo od stava izrečenog u literaturi da se fenomen koji nazivamo prevođenje može adekvatno objasniti uz pomoć teorije relevantnosti (Gutt 1989: 75). Analiziraćemo izvesne načine na koje se engleski pisani diskurs iz oblasti fizike električnih gasnih pražnjenja prevodi na srpski jezik. Upravo nam teorija relevantnosti nudi odgovarajuću aparaturu koja omogućava analizu informacije dva tekstualna uzorka iz oblasti fizike električnih gasnih pražnjenja. Naročito ćemo obratiti pažnju na važnost deskriptivnog prevoda u domenu fizike električnih gasnih pražnjenja, pošto prema literaturi, pretpostavke recipijenata prevoda moraju biti ispunjene čak i na uštrb komunikativnih intencija manifestovanih u polaznom jeziku, a čak i u slučajevima gde bi se više pribegavalo interpretativnom prevodu (Martínez 1998: 171). Takođe, obratili smo pažnju i na slučajeve koji se pominju u literaturi, a odnose se na diskrepance do kojih često dolazi usled dejstva interpretativne sličnosti između onoga što je kodirano i onoga što je saopšteno (Rosales Sequeiros 2001: 197).

Naš izbor teorijskog modela pokazao se kao optimalno solidan, pošto perspektiva usidrena u teoriji relevantnosti može ponuditi teoriji i praksi prevođenja važne parametre koji bi pomogli u poimanju izvesnih kognitivnih procesa potrebnih da se prenesu značenja iz polaznog teksta i namere autora teksta iz polaznog jezika u ciljni jezik. Istovremeno, preliminarni rezultati našeg ispitivanja mogu imati i reperkusije na izvesne seg- 
mente usvajanja engleskog jezika struke, naročito ako semantičku komponentu usvajanja drugog jezika posmatramo kao razmenu unidirekcionog prevoda sa jezika L1 na jezik L2. No, najpre bi trebalo pogledati teorijsku osnovu našeg rada. Najpre ćemo pogledati teorijski okvir koji koristimo u našem istraživanju i u ovom radu.

Ne prenebregavajući eklektički pristupe i modele koje smo koristili u našim ranijim istraživanjima, npr. pristup deskriptivne škole prevođenja iz Tel Aviva (cf. Đurić \& Krnjaić-Cekić, 2014: 64-80; Đurić \& Krnjaić-Cekić 2016: 52-65) koji smo spojili sa CORT modelom prevođenja (Alves and Gonçalves 2003: 3-24). Tokom preliminarnog istraživanja, opredelili smo za teoriju relevantnosti u najvećoj meri zato što se ova teorija usredsređuje na mentalne mehanizme koji omogućavaju recipijentu prevedenog teksta da procesuje na najefikasniji način i uz najmanji napor relevantne informacije iz prevedenog teksta.

Ovaj rad urađen je na teorijskim i metodološkim osnovama teorije relevantnosti ${ }^{1}$. Opredelili smo se za teoriju relevantnosti koja predstavlja aktuelno istraživačko područje lingvističke pragmatike u dodiru sa filozofijom jezika. Intuitivno posmatrano, relevantnost jeste potencijalno svojsto ne samo spoljašnjih stimulansa već i unutrašnjih predstava (Wilson and Sperber 2002b: 46). Sledstveno tome, teorija relevantnosti nudi empirijsko kognitivno-zasnovano objašnjenje ljudske komunikacije (Gutt, 1989: 76). Pored toga, teorija relevantnosti je izuzetno inovativna u domenu shvatanja jezika, kao i kognitivnih i jezičkih procedura koje organizuju komunikativnu interakciju (Martínez, 1998: 171). Ono što je relevantno za prevođenje jeste da pojedini autori smatraju da ovaj teorijski okvir u sprezi sa analizom diskursa može biti pogodan za obuku prevodilaca (cf. Dooley, 2008). Prema pojedinim autorima evaluacija primerenosti prevoda mogla bi se vršiti pragmatičkom primenom teorije relevantnosti (cf. Guillén Galve, 1996).

No, pre nego što krenemo sa objašnjenjem izvesnih aspekata ove teorije, pogledaćemo za trenutak kako se ova teorija bliže određuje u literaturi kao i kratak istorijski razvoj ove teorije.

1 Smatramo da je prevod "teorija relevantnosti“ najoptimalniji srpski prevodni ekvivalent za engleski naziv „Relevance Theory“. Opravdanje za srpski prevodni ekvivalent upravo u ovom obliku našli smo u relevantnoj lingvističkoj literaturi (cf. Polovina, 1996: 50; Žegarac 2005). Sem toga, smatramo da prevodni ekvivalent baš u ovakvom obliku u potpunosti odgovara fonotaktičkim pravilima srpskog jezika. 
Култура и/или наука

\subsection{Teorijski okvir - Un peu de pertinence...}

Teorija relevantnosti se u literaturi određuje kao teorija pragmatike koju su osamdesetih godina XX veka razvijali Sperber i Vilsonova (Matthews 2005: 317). Na dalje, ova teorija se posmatra kao konsolidacija Grajsove teorije konverzacijskih maksima, ali se razlikuje od drugih uvođenjem formalnog koncepta relevantnosti. Na dalje, relevantnost se definiše kao svojstvo, koje bilo koji iskaz, ili propozicija koju ovaj iskaz saopštava, mora nužno da poseduje, prema prirodi komunikacije (Matthews 2005: 317). U opštoj lingvistici, pojam „relevantan“ određuje se kao entitet koji označava lingvistički status nekog obeležja u govoru ili pisanju, a ističe se da je obeležje relevantno ukoliko je kontrastivno (Kristal 1988: 226). U literaturi se navodi da je relevantnost povezana sa skupom postojećih pretpostavki koje sačinjavaju kontekst ili tekuće kognitivno okruženje, u kome se odigrava govorni čin, a pretpostavke koje ovaj govorni čin pridodaje ovom skupu, iako su nužno relevantne, biće relevantne u različitim stepenima (Matthews 2005: 317).

Pošto se pod istraživačkom lupom našeg rada nalazi prevođenje, pogledaćemo kako se teorija relevantnosti tretira u domenu prevođenja. U okviru translatologije, koja je, između ostalog, obuhvaćena ovim radom, konstatuje se da teorija relevantnosti nudi empirijsko objašnjenje ljudske komunikacije zasnovano na kogniciji (Gutt 1989: 76).

Pre stvaranje teorije relevantnosti, izvesni autori su ukazivali na značaj pojma relevantnosti i njegovu pertinentnu ulogu u jeziku, npr. u lingvistici i semiologiji (Prieto, 1975a), ili npr. u fonetici i fonologiji (Prieto). Ovaj autor čak govori i o dvostrukoj relevantnosti (Prieto 1975b). Zatim autori koji pominju relevantnost u konverzaciji, ili konverzacionu relevantnost (Dacal, 1977). A značajna je i autorka koja je analizirala, ali i dovela u vezu pragmatičke konektore i princip relevantnosti (Brockway, 1982). Ipak, formalnim početkom teorije relevantnosti kao jedne formalne lingvističke teorije smatra se datum objavljivanja studije Dana Sperbera i Deirdre Wilson, odnosno, 1986. godina (Sperber and Wilson 1986). No, i pre nego što su formalizovali svoju teoriju, ovi autori su u svojim ranijim radovima postavili temelje za teoriju relevantnosti. U međuvremenu, rad u okviru teorije relevantnosti postao je kolektivni poduhvat (Sperber \& Wilson, 1998: v). Teorija relevantnosti se postepeno stvarala i primenjivala da bi Vilson 
i Sperber uobličili teoriju relevantnosti sredinom devedesetih godina XX veka (Polovina, 1996: 45)².

Teorija relevantnosti, kao jedna teorija ljudske komunikacije i spoznaje, zasniva se na gledištu da ljudi imaju psihološku (biološku) predispoziciju da obraćaju pažnju na demonstrativne stimulanse (Žegarac 2005: 17).

Teorija relevantnosti polazi od pretpostavke da je čovekov kognitivni sistem usmeren ka maksimalnoj relevantnosti, ili preciznije, ka postizanju najvećeg broja kognitivnih efekata uz najmanji utrošak procesualnog napora u obradi informacija. Na dalje, relevantnost se određuje i kao mera efikasnosti u ljudskoj spoznaji i komunikaciji (Žegarac, 2005: 17). Glavni predmet proučavanja teorije relevantnosti jesu misli (koje su privatne i neopažljive) i demonstrativni činovi (koji su javni i opažljivi), a čiji je cilj saopštavanje misli. Komunikativna intencija može se izraziti različitim činovima, kako verbalnim, tako i neverbalnim, pri čemu su posredi isti inferencijalni procesi, nezavisno od toga da li se kombinuju sa kodiranom informacijom. U okviru teorije relevantnosti, relevantnost se tretira kao svojstvo inputa kognitivnim procesima (Wilson, 1999: 719; Wilson \& Sperber, 2000: 230), postavlja se pitanje razgraničenja semantike i pragmatike, a istovremeno se otvara prostor za nove teorije o interpretaciji iskaza i o samoj strukturi diskursa.

Teorija relevantnosti tvrdi da su očekivanja relevantnosti koja su inicirana iskazom dovoljno precizna, kao i dovoljno prediktivna, da rukovod slušaoca prema govornikovom značenju (Wilson and Sperber 2002b: 46).

Pošto kontekst ima pertinentnu ulogu u procesu prevođenja, pogledaćemo i kako se tretira u okviru teorije relevantnosti. Između ostalog, relevantnost se definiše kao odnos između iskaza i konteksta (Polovina, 1996: 45). Kako to Polovina ističe, „Iskaz je relevantan ako i samo ako su izražene propozicije kompletirane s podskupom konteksta tako da mogu služiti kao baza za argumentaciju iz koje proizilazi netrivijalni zaključak." (Polovina, 1996: 45). Relevantnost konteksta ogleda se, između ostalog, i u centralnoj hipotezi o pojmu transderivacione zapreke osetljive na kontekst koja se zasniva na tome da valjano oblikovani iskazi jesu osetljivi na kontekst i zavise od konteksta (npr. Brockway, 1982: 9). Pojam konteks-

2 Pregled literature teorije relevantnosti obezbedio je Francisco Yus Ramos u svom sveobuhvatnom pregledu (Yus Ramos 1998: 305-345). 
Култура и/или наука

ta u teoriji relevantnosti se uglavnom primenjuje na adresata, odnosno, na način na koji on konstantno upoređuje novu informaciju sa onom pohranjenom u dugoročnoj memoriji sa ciljem da se povrate adekvatni kontekstualni efekti koji će mu dozvoliti da uskladi značenje izvedeno na osnovu zaključka sa podležnim intencijama originalog teksta. Dakle, kontekst ima relevantnu ulogu i u procesu prevođenja i u teoriji relevantnosti Sperbera i Vilsonove.

Osnovno kognitivno usmerenje teorije relevantnosti zasnovano je na pretpostavci da je ljudski kognitivni sistem usmeren ka maksimalnoj relevantnosti (Sperber \& Wilson, 1987: 740; Wilson, 1999: 719; Wilson \& Sperber, 2002a: 50; Wilson \& Sperber, 2002b: 254; Wilson \& Sperber, 2004: 610), odnosno ka postizanju najvećeg broja kognitivnih efekata uz najmanji utrošak procesualnog napora. Drugim rečima, ovo usmerenje formulisano je kao prvi princip relevantnosti, koji se naziva još i kognitivni princip relevantnosti (Sperber \& Wilson, 1995: 260), a koji, prema Sperberu i Vilsonovoj glasi: „Ljudski kognitivni procesi jesu usmereni ka obradi najrelevantnije raspoložive informacije na najrelevantniji način" (Sperber \& Wilson, 1995: 260) (prevod sa engleskog: M. D. Đurić \& N. Krnjaić-Cekić).

Vilsonova i Sperber smatraju da su relevantnost i postizanje maksimalne relevantnosti zapravo ključ ljudske kognicije (Wilson \& Sperber, 1994: 91). Perceptualni sistemi automatski reaguju na stimulanse koji mogu dovesti do kognitivnih efekata. Ovi stimulansi se, potom, transformišu u sheme reprezentacije i na taj način dospevaju u konceptualne sisteme inferencije. $U$ toj tački, oni se povezuju što efikasnije sa izvesnim postojećim aktiviranim reprezentacijama sa ciljem da se dobije što više kognitivnih efekata.

U okviru teorijskog okvira relevantnosti informacija koja se saopštava nameće izvesno očekivanje relevantnosti. Naime, govornik zahteva sagovornikovu pažnju, a sagovornik dobija određene kognitivne efekte koji su vredni date pažnje. Vilsonova i Sperber kažu da svaki čin inferencijalne komunikacije stvara očekivanje optimalne relevantnosti, a veruju da je ovaj jedinstveni princip sam za sebe dovoljan da omogući jednu eksplanatornu pragmatičku teoriju (Wilson and Sperber 1994: 96). Ovde je relevantan zapravo utrošak procesualnog napora, što je formulisano pomoću drugog komunikativnog principa relevantnosti koji glasi: „Svaki čin demonstrativne komunikacije saopštava pretpostavku o sopstvenoj optimalnoj rel- 
evantnosti“ (Sperber \& Wilson, 1995: 260, prevod sa engleskog: M. D. Đurić \& N. Krnjaić-Cekić).

Pored navedenog principa relevantnosti, bitan je pojam optimalne relevantnosti kako bi se bolje sagledao i shvatio komunikativni princip. Drugim rečima, prema Sperberu i Vilsonovoj, demonstrativni stimulans dovoljno je relevantan da zavredi sagovornikov napor da ga obradi. Isto tako, demonstrativni stimulans je najrelevantniji stimulans prema govornikovim sposobnostima i sklonostima (Sperber \& Wilson, 1995: 270). Sledstveno tome, relevantnost je ravnoteža koja se uspostavlja između kognitivnih (tj. kontekstualnih) efekata i procesualnog napora (pažnja, memorija, inferencija).

U okviru teorije relevantnosti bitno mesto zauzima i kontekst „propozicije“, pa ćemo pogledati i njega. Naime, u teoriji relevantnosti, kaže se da iskazi izražavaju propozicije, a propozicije su istinosno uslovljene (Wilson \& Sperber, 1993: 1). Propozicija, ili kako se još naziva u teoriji relevantnosti, propozicionalna forma, prema Karstonovoj, može da se sagleda kao valjano oformljena formula koja podleže logičkim operacijama, sa očuvanjem istinitosti, koje su utvrđene njenom strukturom, a semantički je potpuna tako što može biti istinita ili pak neistinita (Carston, 1991: 49; prevod i parafraza M. D. Đurić \& N. Krnjaić-Cekić). Potrebno je odrediti i termine „eksplikatura“ i „implikatura“, koji imaju važnu ulogu u teoriji relevantnosti.

Prema relevantnoj lingvističkoj literaturi, pretpostavke koje govornik namerava da saopšti mogu se preneti na dva različita načina u okviru teorije relevantnosti, i to: kao eksplikature i kao implikature (Gutt, 1989: 80). Prema Sperberu i Vilsonovoj, pretpostavka saopštena u iskazu I je eksplicitna ako i samo ako je nastala razvojem neke logičke forme koju kodira I (Sperber \& Wilson, 1995: 182). Svakako, treba imati na umu, da u slučajevima ambigviteta, tj. dvosmislenosti i višesmislenosti površinska struktura kodira nekoliko logičkih formi. Na dalje, Sperber i Vilsonova ističu da pretpostavka saopštena u iskazu I koja nije eksplicitna jeste implicitna (Sperber \& Wilson, 1995: 182).

U okviru teorije relevantnosti, kontekst koji se koristi u interpretaciji iskaza ograničen je organizacijom enciklopedijske memorije, perceptualnim i kognitivnim sposobnostima i mentalnom aktivnošću kojom je pojedinac zaokupljen. Kada govore, između ostalog, o aproksimacijama, 
Sperber i Vilsonova takođe prizivaju u pomoć kontekst, pa kažu da prihvatljivost aproksimacija varira sa sadržajem, ali i kontekstom (Wilson \& Sperber, 2000: 225). Sada ćemo, na trenutak, pogledati razliku između semantike i pragmatike u okviru teorije relevantnosti.

Klasično poimanje pragmatike Grajsove provenijencije povlači znak jednakosti između jezičkog značenja i istinosno uslovljenog sadržaja. Drugim rečima, može se uspostaviti formula prema kojoj je pragmatika jednaka značenju od koga se oduzimaju istinosni uslovi (Levinson, 1983). Preciznije to bi moglo biti predstavljeno na sledeći način: „Pragmatika = značenje - istinosni uslovi“ (što čitamo: „pragmatika jednako značenje minus istinosni uslovi“). U okviru teorije relevantnosti, razlika između semantike i pragmatike može da se posmatra kao razlika između dekodiranja i inferencije. To je onda razlika između dve vrste kognitivnih procesa koji se odigravaju prilikom razumevanja datog iskaza (Sperber \& Wilson, 1995). Vilsonova i Sperber navode da je pragmatika proučavanje opštih kognitivnih principa i sposobnosti obuhvaćenih interpetacijom iskaza i njihovih kognitivnih efekata (Wilson \& Sperber, 1994: 85).

Već u ovim razlikama između teorije relevantnoti i Grajsovog pristupa relevantnosti može se uočiti napredak kognitivne teorije relevantnosti Vilsonove i Sperbera u odnosu na Grajsa. Prema literaturi, „ova teorija relevantnosti je mnogo eksplicitnija nego Grajsove maksime u razgovoru među kojima je jedan od principa i relevantnost, kao stepen kooperativnosti [...]" (Polovina, 1996: 49).

Prema ovom teorijskom modelu, autonomni jezički sistem, koji je jezički perceptualni modul, odnosno, parser ili prevodilac učestvuje u procesu dekodiranja. Drugim rečima, ovako ustrojen sistem identifikuje dati akustički ili grafički stimulans kao jezički, a onda obavlja niz algoritamskih, gramatičkih operacija prevođenja, a kao rezultat dobijamo logičku formu. Ova logička forma jeste zapravo semantička reprezentacija rečenice ili fraze koja se koristila u iskazu.

Prema literaturi, logička forma se određuje kao nivo jezičke reprezentacije, a postavlja se i zasebno pitanje o vezi između sintaksičkog oblika i logičke forme (May, 1986: 1). Autori koji se u svojim radovima eksplicitno bave logičkom formom ističu da kada jednom napravimo distinkciju semantičkog tipa između kvantifikacijskih i referencijalnih izraza kao osnovnu, onda se sintaksičke paradigme koje se nalaze u logičkoj formi mogu 
posmatrati kao posledice zahteva za prevođenje argumentske strukture na logičku formu (May, 1986: 26). Na dalje, logička forma se smatra strukturisanim nizom koncepata sa logičkim i kauzalnim karakteristikama. U izvesnim slučajevima, logička forma nije propozicionalna. Sledstveno tome, logička forma služi kao shema koja se razvija u propoziciju koju je sagovornik želeo da izrazi i to na osnovu pragmatičke inferencije.

Drugim rečima, jezički parser kod akustičkih i grafičkih verbalnih stimulansa obavlja gramatičke operacije i daje autput u vidu semantičke reprezentacije verbalnog stimulansa, ili preciznije logičku formu. Na dalje, logička forma služi kao input pragmatičkog procesora. Treba naglasiti da se isključivo kodno formirana logička forma dopunjuje inferencijalno do propozicije koja ima ulogu inputa za semantiku istinosnih uslova. I ostali vidovi značenja verbalnog stimulansa, koji su u domenu pragmatičkog procesora, inferencijalno se izvode na osnovu kodno-inferencijalnog amalgama, tj, propozicionog amalgama.

Izvođenje eksplicitno saopštene propozicije, tj. eksplikature, zavisi od pragmatičkih inferencijalnih procesa, ili preciznije, zavisi od dodeljivanja referencije, zasićenja, obogaćenja, razrešenja ambigviteta (odnosno dvosmilenosti ili višesmislenosti) i podešavanja koncepata. Prema ovom okviru, jezička semantika i pragmatika u sadejstvu daju propozicionalne forme koje mogu poslužiti kao ulaz za istinosno uslovljenu semantiku.

Umesto zaključka, u ovom kratkom nepretencioznom osvrtu na osnovne postavke teorije relevantnosti, izneli bismo jedno lucidno zapažanje: „[...] pojam relevantnost, i reči izvedene iz njega, možemo definisati kao svojstvo od značaja za kogniciju uopšte, za sve komponente kognitivne aktivnosti u toku stvaranja i primanja informacija [...]" (Polovina, 1996: 51). Na kraju, ne treba smetnuti sa uma da svojstvo relevantnosti jeste „[...] prisutno ne samo u neposrednoj govornoj komunikaciji nego i u svim vrstama ljudske komunikacije“ (Polovina, 1996: 51).

U narednom delu rada, pogledaćemo kako se prevođenje sagledava iz ugla teorije relevantnosti.

\subsection{Teorija relevantnosti i prevođenje}

Autori koji se bave prevođenjem iz ugla teorije relevantnosti iznose konstatacije da se prevodi mogu analizirati kao varijante interpretativne 
Култура и/или наука

upotrebe (Gutt, 1989: 75). Ističe se i važnost deskriptivnog prevoda, kako u slučajevima gde se inače izražava veća sklonost ka tradicionalnom prevodu, tako i u primerima gde se moraju ispuniti pretpostavke adresata čak i po cenu komunikativnih intencija manifestovanih u polaznom jeziku (Martínez 1998: 171). U literaturi koja analizira prevod iz ugla teorije relevantnosti, autori se, uglavnom, slažu da ponekada dolazi do diskrepanci u prevodu usled dejstva interpretativne sličnosti između onoga što se kodira i onoga što je saopšteno (Rosales Sequeiros 2001: 197). Autori takođe konstatuju da svi slučajevi prevođenja mogu objasniti kao slučajevi demonstrativno-inferencijalne komunikacije (Gutt 1989: 77), a prema citiranom autoru, suštinski sastojci demonstrativno-inferencijalne komunikacije su: komunikator, stimulans, publika i skup pretpostavki $\{1\}$ koje se nameravaju saopštiti.

Prema teoriji relevantnosti, pretpostavke koje komikator namerava da saopšti mogu da se prenesu na dva različita načina: kao eksplikature i kao implikature (Gutt 1989: 80). Kaže se i da prevodioci pokušavaju da zadovolje kognitivna očekivanja recipijenata izvornog teksta (Martínez 1998: 174). Za prevođenje je potrebno i adekvatno shvatanje teksta, koje se u ovoj literaturi određuje kao izvođenje nameravanih propozicionih formi iskaza koje ovaj tekst sadrži, a da bi prevodilac ovo učinio, često mora ići izvan jezički kodiranog sadržaja teksta i izvući informaciju iz konteksta, kako bi izveo puniju propozicionu formu (Rosales Sequeiros 2001: 199).

U ovim, i slično profilisanim radovima, pridaje se pažnja i međujeziku. Preciznije, ukoliko se zahtevi za relevantnošću u obe poruke (namera + demonstracija + kontekstualni efekti + inferencija + pretpostavke) podjednako realizuju, onda se razlike među njima mogu objasniti u smislu međujezika umesto uključenih kognitivnih efekata (Martínez 1998: 176). Pored toga, jaz između onoga što je kodirano i onoga što je saopšteno ima značajne posledice za prevod (Rosales Sequeiros 2001: 198).

\subsection{Primena teorije relevantnosti}

u prevođenju diskursa fizike električnih gasnih pražnjenja

U literaturi se pominju načini na koje saopšteni koncept može da odstupi od kodiranog koncepta. Ovo je relevantno za prevođenje, naročito pisanog i usmenog diskursa iz oblasti fizike električnih gasnih pražnjenja. 
Načini odstupana kodiranih koncepata su: sužavanje (ojačavanje) koncepta, širenje (oslabljivanje) koncepta i odjekivanje koncepta (Rosales Sequeiros 2001). Za naš slučaj prevođenja, relevantan je i pojam interpretativne sličnosti, pošto ima reperkusije na proces prevođenja. Naime, prema okviru teorije relevantnosti, kada dve propozicionalne reprezentacije dele analitičke i kontekstualne implikacije javlja se intrepretativna sličnost. Ono što bi moglo biti relevantno za prevođenje jeste kontekstualna uslovljenost intrerpretativne sličnosti. Naime, propozicije $P$ i $Q$ mogu biti sličnije u jednom, a manje slične u drugom kontekstu, ili pak nimalo slične u trećem kontekstu. Ovo ćemo ilustrovati primerima prema modelu iz literature (Sperber and Wilson 1986), s tim što su svi ekscerpti iz našeg korpusa fizike električnih gasnih pražnjenja.

(a) Local theromodynamic equilibrium exists between all plasma components.

(b) Most of the optical radiation arises from a mechanism which depends on the temperature of the electrons as well as that of the atoms.

(c) If local thermodynamic equilibrium exists between all plasma components, then most of the optical radiation arises from a mechanism which depends on the temperature of the electrons as well as that of the atoms.

(d) If most of the optical radiation arises from a mechanism which depends on the temperature of the electrons as well as that of the atoms, then the intensity of radiation arising from recombination of a free electron into a certain atomic state will depend on the volume density of singly ionized atoms.

(e) If local thermodynamic equilibrium exists between all plasma components, the volume density depends on the ion temperature.

(f) If most of the optical radiation arises from a mechanism which depends on the temperature of the electrons as well as that of the atoms, microwave emission from a plasma should arise almost entirely from electron emission mechanisms.

(g) The optical radiation arises from a mechanism which depends on the temperature of eletrons and atoms.

(h) The radiation emitted due to the acceleration of the electron during a collision with an ion or atom or cyclotron emission due to the ac- 
celeration if an electron spiraling in a dc magnetic field should not depend strongly on atom and ion temperatures.

Propozicije (a) i (b) sličnije su u kontekstu (c-d) nego u kontekstu (e-f). Malo preciznije, u prvom kontekstu propozicije (g) i (h) imaju implikacije. Odnosno, propozicija (a) kontekstualno implicira (g), propozicija (b) analitički implicira (g). Na dalje, propoziciju (h) obe kontekstualno impliciraju, a u drugom kontekstu uopšte nemaju zajedničke implikacije.

Bitno je napomenuti da u ovom modelu pertinentno mesto zauzima, između ostalog, i shvatanje, koje se određuje kao proces koji radi na vezi, a hipoteze o eksplikaturama, impliciranim premisama i impliciranim zaključcima se razvijaju paralelno uz prethodno znanje očekivanja (Sperber and Wilson 2002a: 12). Da bismo ilustrovali upravo iznete konstatacije, pogledaćemo razmenu u primeru (1):

(1) a. X: Did an electron make ellastic collision with a gas atom. b. Y: No. Its energy was insufficient to excite the target atom.

Ovu razmenu ćemo ilustrovati sledećom tabelom, čiju smo strukturu u potpunosti preuzeli iz literature (2002a: 12-13), s tim što su svugde uneti primeri iz našeg korpusa, i naša tumačenja. Naime, u našoj tabeli se nalazi shematski prikaz kako bi sagovornik X mogao da iskoristi proceduru shvatanja prema teoriji relevantnosti kako bi konstruisao hipoteze o eksplikaturama i implikaturama iskaza sagovornika Y, „Its energy was insufficient to excite the target atom".

\begin{tabular}{|c|c|}
\hline $\begin{array}{l}\text { (a) Sagovornik } Y \text { je rekao sagovorniku } \\
X, \text { Its }_{x} \text { energy was insufficient to excite } \\
\text { the TARGET ATOM. } \\
\text { [Its }_{x}=\text { neinterpretirana prisvojna } \\
\text { zamenica] } \\
\text { [TARGET ATOM }_{1}=\text { atom mete] } \\
\text { [TARGET ATOM }{ }_{2}=\text { nivoi karakteristični } \\
\text { za atom mete] }\end{array}$ & $\begin{array}{l}\text { Uklapanje dekodirane (nepotpune) } \\
\text { logičke forme iskaza govornika Y u opis } \\
\text { demonstrativnog ponašanja govornika Y. }\end{array}$ \\
\hline $\begin{array}{l}\text { (b) Iskaz Y je optimalno relevantan } \\
\text { za X. }\end{array}$ & $\begin{array}{l}\text { Očekivanje do koga se došlo priznavanjem } \\
\text { demonstrativnog ponašanja Y i prihvatanjem } \\
\text { pretpostavke o relevantnosti koju ovaj iskaz } \\
\text { prenosi. }\end{array}$ \\
\hline
\end{tabular}




\begin{tabular}{|l|l|}
\hline $\begin{array}{l}\text { (c) Iskaz Y će postići relevantnost } \\
\text { objašnjavanjem zašto X konstatuje } \\
\text { da je energija bila nedovoljna za da } \\
\text { pobudi atom mete. }\end{array}$ & $\begin{array}{l}\text { Očekivanje koje inicira (b), zajedno sa } \\
\text { činjenicom da bi takvo objašnjenje bilo } \\
\text { najrelevantnije za X u ovom trenutku. }\end{array}$ \\
\hline $\begin{array}{l}\text { (d) Kada energija nije dovoljna da } \\
\text { pobudi neke od nivoa ATOMA METE }{ }^{\prime} \\
\text { elektron može da vrši samo elastične } \\
\text { udare sa atomima gasa. }\end{array}$ & $\begin{array}{l}\text { Prva pretpostavka koja pada napamet X, koja } \\
\text { bi sa ostalim odgovarajućim premisama mogla } \\
\text { da zadovolji očekivanje (c). Prihvata se kao } \\
\text { implicitna premisa iskaza Y. }\end{array}$ \\
\hline $\begin{array}{l}\text { (e) Enegija nije bila dovoljna da } \\
\text { pobudi atome neke od nivoa ATOMA } \\
\text { METE }{ }_{1} \text {. }\end{array}$ & $\begin{array}{l}\text { Prvo obogaćenje logičke forme iskaza Y koje } \\
\text { pada napamet X a koje se može kombinovati } \\
\text { sa (d) i voditi zadovoljenju (c). Prihvata se kao } \\
\text { eksplikatura iskaza govornika Y. }\end{array}$ \\
\hline $\begin{array}{l}\text { (f) An electron did not make ellastic } \\
\text { collision with a gas atom because its } \\
\text { energy was insufficient to excite the } \\
\text { TARGET ATOM } .\end{array}$ & $\begin{array}{l}\text { Ovim se dolazi inferencijom na osnovu (d) i } \\
\text { (e), zadovoljava (c) i prihvata se kao implicitan } \\
\text { zaključak iskaza Y. }\end{array}$ \\
\hline $\begin{array}{l}\text { (g) An electron may make ellastic } \\
\text { collision with a gas atom when its } \\
\text { energy becomes sufficient to excite } \\
\text { the TARGET ATOM. }\end{array}$ & $\begin{array}{l}\text { Iz (f) plus prethodno znanje. Jedna od nekoliko } \\
\text { mogućih slabih implikatura iskaza Y koji, } \\
\text { zajedno sa (f), zadovoljavaju očekivanje (b). }\end{array}$ \\
\hline
\end{tabular}

Tabela 1.3.1.

Iz tabele 1.3.1. vidimo da govornik $X u(1.3 .1 b)$ pretpostavlja da iskaz govornika $\mathrm{Y}$, dekodiran kao (1.3.1a), jeste optimalno relevantno za X. Pošto je sve što želi da zna u ovom trenutku zašto je elektro nije izvršio elastičan sudar sa atomima gasa, a pretpostavlja u (1.3.1c) da će iskaz Y postići relevantnost odgovorom na ovo pitanje. U ovim okloknostima, logička forma iskaza obezbeđuje lak pristup kontektualnoj pretpostavci u (1.3.1d), a ona se može koristiti kao implicitna premisa prilikom izvođenja očekivanog objašnjenja ponašanja $X$, pod uslovom da je iskaz interpretiran na eksplicitnoj strani putem disambiguacije i razrešenja reference kao takav da prenosi informaciju u (1.3.1e). Kombinovanjem implicitne premise $u(1.3 .1 \mathrm{~d})$ i eksplicitne premise $u(1.3 .1 \mathrm{e}), \mathrm{X}$ dolazi do implicitnog zaključka u (1.3.1f), iz koga dalje, slabije implikature, koje obuhvataju (1.3.1g) i druge, mogu da se izvedu. Rezultujuća ukupna interpretacija zadovoljava X-ovo očekivanje relevantnosti. U tom smislu, do eksplikatura i implikatura (tj. implicitnih premisa i zaključaka) dolazi se procesom uzajamnog paralelnog podešavanja. Sperber i Vilsonova napominju da je ipak ovakav shematski prikaz previše pojednostavljen (Sperber and Wil- 
Култура и/или наука

son 2002a: 14), međutim, sasvim je dovoljan za našu analizu i za zaključke koje izvodimo na osnovu toga.

\subsection{Interpretativne strategije i prevođenje diskursa fizike električnih gasnih pražnjenja}

U okviru teorije relevantnosti uvode se i dva pojma: interpretativna reprezentacija $\mathrm{i}$ interpretativna strategija. Interpretativna reprezentacija, bilo da je mentalna ili javna, jeste takva reprezentacija sa kojom je po logičkom, semantičkom, konceptualnom sadržaju slična. Drugi (komunikativni) princip relevantnosti nameće određenu interpretativnu strategiju, koju Karstonova, objašnjavajući odnos generativne gramatike i pragmatike usidrene u teoriji relevantnosti, formuliše na sledeći način. Karstonova smatra da bi moguće kognitivne efekte trebalo razmatrati prema redosledu njihove pristupačnosti, odnosno sledeći put najmanjeg napora. Takođe, potrebno je stati kada se postigne očekivani nivo relevantnosti, ili kada taj nivo izgleda neostvarljiv (Carston, 1999: 8).

Pogledaćemo sledeću razmenu u ekscerptu iz našeg korpusa fizike električnih gasnih pražnjenja:

(1) $\quad X$ : Shall we consider the effects of long-range forces?

$Y$ : The force of interaction is cut off at the Debye length.

Sagovornik X mora da uloži dodatni inferencijalni napor bi razumeo odgovor sagovornika Y. Istovremeno, međutim, on dobija i dodatne efekte, a sve ovo može se ilustrovati shematski sledećim pragmatičkim procesima koje je Karstonova (Carston, 2002: 140) modelovala prema Sperberu i Vilsonovoj (cf. Wilson \& Sperber, 2000).

(2) (a) rečenica sagovornika Y ima logičku formu [The force of interaction is cut off at the Debye length] (Ovo je autput jezičkog dekodiranja, odnosno, izlaz jezičkog dekodiranja).

(b) Iskaz sagovornika $Y$ je optimalno relevantan za sagovornika X. (Ovo je pretpostavka o relevantnosti). 
(c) Iskaz sagovornika Y postaje relevantan time što odgovara na pitanje sagovornika X. (Ovo je standardno očekivanje relevantnosti kada se radi o pitanjima).

(d) Pri razmatanju efekata sila sa dejstvom na daljinu u teoriji sudara, može se pokazati da interakciona sila treba da se odseče na Debijevoj dužini. (Ovo je krajnje pristupačna pretpostavka kojom se pospešuje odgovor na pitanje sagovornika $X)$.

(e) Sila interakcije treba da se odseče na Debijevoj dužini tamo gde se razmatraju efekti sa dejstvom na daljinu. (prvo pristupačno obogaćenje iskaza sagovornika Y koje može da se kombinuje sa (d) u odgovoru na pitanje sagovornika $\mathrm{X}$ ).

(f) U teoriji sudara kod efekata sila sa dejstvom na daljinu (verovatno) sila interakcije treba da se odseče na Debijevoj dužini. (Ovo je izvedeno iz (d) i (e), zadovoljava (c) i postaje implikatura iskaza sagovornika Y).

(g) Sila interakcije mora da se odseče na Debijevoj dužini, zato što je to potrebno razmotriti efekte sa dejstvom na daljinu u teoriji sudara. (Ovo je vrlo pristupačna implikatura izvedena iz (d) i (e) koja zajedno sa (f) i drugim implikaturama zadovoljava (b), standardno očekivanje relevantnosti).

(h) Sagovornik X i Y mogu da sagledaju i nešto drugo. Mogu da uzmu u obzir debljinu graničnog sloja, koji se stvara između plazme i površine suda.

Kao što smo ilustrovali primerima (2a-2h), koji su modelovani prema pragmatičkim procesima Karstonove, saopštene propozicije se uzajamno paralelno podešavaju, te stoga inferencijalni proces ide od eksplikature ka implikaturi i obrnuto. Uloga pragmatičkog sistema je da dođe do značenja sagovornika $Y$, ili preciznije, do onoga što je sagovornik $Y$ nameravao. Ne manje relevantna uloga u ovom okviru jeste i uloga koju ima kontekst. Sperber i Vilsonova smatraju da se sagovornici pokušavaju da odaberu kontekst koji će maksimalno povećati relevantnost. Oni još preciznije konstatuju da se naročito u verbalnom razumevanju relevantnost tretira kao data, a kontekst se tretira kao promenjljiva (Sperber \& Wilson, 1995: 142).

\subsection{Analiza primera iz korpusa}

Osnovni postulati naznačenog teorijskog aparata primenjeni su u analizi uzoraka tekstova prevednih sa engleskog na srpski jezik i u kon- 
Култура и/или наука

trastivnoj analizi koju smo sproveli na konkretnom jezičkom materijalu iz oblasti fizike električnih gasnih pražnjenja. No pre nego što krenemo sa konkretnim primerima tekstualnih ekscerpata, pogledaćemo kako se u okviru pragmatike teorije relevantnosti sagledavaju pojmovi na primeru jednog leksičkog ajtema iz našeg korpusa.

(3) Let us now refine our collision picture further.

Analiza primera (3) zasnovana je na pragmatičkom procesu obogaćenja od logičke forme ka propoziciji iskaza zasnovana na konceptualnoj modulaciji leksički kodiranog izraza COLLISION da bi se dobio ad hoc koncept COLLISION*, koji ulazi kao konceptualni istinosno-vrednosni konstituent propozicije iskaza. Kao što vidimo i u diskursu fizike električnih gasnih pražnjenja, saopšteni ad hoc koncept može da postane konstituent konceptualne reprezentacije iskaza osnovne propozicije, koji potom generiše pertinentan skup implikatura. Upravo u primeru (3) iz našeg korpusa, možemo primetiti da iako se radi o strogo definisanom diskursu, ipak se javlja pragmatičko oslabljivanje značenja, ili, prema terminologiji Sperbera i Vilsonove, dolazi do labave upotrebe jezika (Sperber \& Wilson, 1986: 153-171).

Naravno, ukoliko zanemarimo implikature i labavu upotrebu jezika, mi uvek možemo procesovati „čiste“ ekvivalente u prevodu, koji se u relevantnoj literaturi definišu kao „lekseme ili fraze jezika-cilja koje su u konkretnom kontekstu, imajući u vidu tekst kao celinu, ekvivalentne određenim izražajnim sredstvima originala" (Kostić, 2006: f. 123, 215). Svakako, nismo zanemarili ni mogućnost umetanja leksikografskog ekvivalenta, koji se nalazi u dvojezičnom rečniku, što bi moglo da se izvrši i u slučaju ad hoc koncepta COLLISION*. Ovde se vredi podsetiti da leksikografski ekvivalenti bilingvalnih rečnika jesu lekseme „jezika-cilja, tj. njihove seme, koje se nalaze u odnosu leksikografske ekvivalencije sa odgovarajućom odrednicom, tj. leksemom jezika-izvora (tj. njenim sememama) (Kostić, 2006: 215).

Kada se pominje teorija relevantnosti u literaturi koja se bavi njenom primenom u prevođenju, postavlja se pitanje koja je moguća veza teorije relevantnosti sa prevođenjem (Kliffer \& Stroińska, 2004: 166). Autori koji se kreću u ovim teorijskim okvirima kažu da interpretativna upotreba 
jezika obuhvata pojave tako disparatne poput indirektnog govora, ironije, parodije i prevođenja (Gutt, 1989; Kliffer \& Stroińska, 2004). Njihovu konstataciju da prevedeni tekst interpretativno liči na drugu reprezentaciju, pre no što je direktni opis nekog stanja stvari. Sličnost zavisi od prevodiočevog vrednovanja koliko je relevantan svaki vid sadržaja za tumača teksta autputa.

Oslanjajući se na reprezentativnu literaturu, polazimo od hipoteze koja se iznosi u literaturi, prema kojoj se svi slučajevi ljudskog prevođenja mogu objasniti kao slučajevi demonstrativno-inferencijalne komunikacije (Gutt, 1989: 77). Prema citiranom autoru, suštinski sastojci demonstrativno-inferencijalne komunikacije su: saopštavalac poruke, stimulans, publika (tj. recipijenti) i skup pretpostavki $\{l\}$ koje treba da se saopšte (Gutt, 1989: 77). Kada se ovo primeni na prevođenje, javlja se osam sastojaka i to četiri sastojka za polazni jezik (originalni saopštavalac poruke, originalni tekst/iskaz, originalna publika i značenje originala) i četiri sastojka za ciljni jezik (prevodilac, prevedeni tekst/iskaz, publika jezika-recipijenta, značenje prevedenog teksta) (prema Gutt, 1989: 78).

Konstatujući da prevođenje obuhvata dva paralelna skupa faktora, Gut postavlja pitanje u kojim se odnosima oni nalaze, a to pokušava da razreši tako što postavlja sledeća četiri pitanja (Gutt, 1989: 78): 1. Ko je saopštavalac u demonstrativno-inferencijalnoj komunikaciji?, 2. Kakav je stimulans?, 3. Ko je publika (ko su recipijenti?), 4. Kakav se skup pretpostavki \{l\} namerava saopštiti? (Gutt, 1989: 78).

Pogledaćemo primer iz našeg korpusa tekstova iz oblasti fizike električnih gasnih pražnjenja, odnosno, engleski original (ekscerpt 1) i naš prevod na srpski jezik ${ }^{3}$ (ekscerpt 1a).

\section{Ekscerpt 1.}

In the presence of collisions, Newton's second law may be written, and the velocity is $m \frac{d v}{d t}+\left(m v_{m}\right) v=-e E_{0} e^{j \omega t}$

$v=\left(\frac{-e / m}{j \omega+v_{m}}\right) E$

where $E=E_{0} e^{j \omega t}$.

3 Kako ne bismo opterećivali dodatnim objašnjenima praćenje originala i prevoda, napominjemo da su sve ekscerpte sa engleskog na srpski preveli: Miloš D. Đurić i Nada Krnjaić-Cekić. 
Култура и/или наука

\section{Ekscerpt 1a.}

Uzimajući u obzir sudare, Njutnov drugi zakon može se napisati u obliku

$m \frac{d v}{d t}+\left(m v_{m}\right) v=-e E_{0} e^{j \omega t}$

sa brzinom $v$ datom izrazom $v=\left(\frac{-s / m}{j \omega+v_{m}}\right) E$

gde je $E=E_{0} e^{j \omega t}$.

Kada pogledamo ova dva ekscerpta moramo se složiti sa pomenutim autorima (Gutt, 1989; Kliffer \& Stroińska, 2004) koji ponavljaju Jakobsonovu ocenu da je prevođenje samo druga semiotička transpozicija koja se fundamentalno ne razlikuje od parafraze. U ekscerptima 1 i 1 a vidimo interpretativnu upotrebu na delu. $U$ ekscerptu 1 u engleskom polaznom tekstu imamo samo izraz ", and the velocity is", međutim, u srpskom prevodu, a u skladu sa primenom teorije relevantnosti u prevođenju, moramo dodati interpetaciju koja će preciznije odrediti niz koji prevodimo, pa tako naš prevod glasi „sa brzinom v datom izrazom“. Ovde vidimo na delu i ono što Gut naziva labavijim stepenom istinitosti („looser degree of faithfulness", vidi Gutt, 1989: 75). Pogledaćemo sada ekscerpt 2 i prevod na srpski (ekscerpt 2a).

\section{Ekscerpt 2.}

The probability of attachment per collision $h$ is not the only common attachment quantity. The probability of attachment per centimeter of travel, $\beta$ is used by analogy to the ionization coefficient $\alpha$. Thus $\frac{\beta}{p}=f\left(\frac{E}{p}\right)$ as $\frac{\alpha}{p}=f\left(\frac{E}{p}\right)$.

\section{Ekscerpt 2a.}

Verovatnoća pripajanja po sudaru, $h$, nije jedina opšta veličina procesa pripajanja. Po analogiji sa jonizacionim koeficijentom $\alpha$, definiše se verovatnoća pripajanja po centimetru puta, $\beta$. Tako je $\frac{\beta}{v}=f\left(\frac{E}{v}\right)$ kao što je $\frac{\alpha}{p}=f\left(\frac{E}{p}\right)$. 
Ovo je ilustrativni primer slučaja demonstrativno-inferencijalne komunikacije. Kao što se vidi, prevodioci žele da modifikuju kognitivno okruženje ciljne publike, odnosno, okruženje recipijenata prevoda. Engleski original „The probability of attachment per centimeter of travel, $\beta$ is used by analogy to the ionization coefficient $\alpha$ " prevodi se na srpski kao „Po analogiji sa jonizacionim koeficijentom $\alpha$, definiše se verovatnoća pripajanja po centimetru puta, $\beta$ “. Kao što vidimo, prevodioci su se potrudili da proizvedu stimulans u ciljnom jeziku kako bi saopštili informativnu nameru polaznog jezika. Analizirajući ekscerpt 2a primećujemo da teorija relevantnosti može da bude od pomoći u procesu prevođenja. Upravo interpretativna upotreba nam dozvoljava da iskaze/rečenice koristimo deskriptivno, odnosno, kao istinske opise nekog stanja stvari, a mogu se koristiti i interpretativno, a to znači da se iskazi/rečenice upotrebljavaju na osnovu svoje sličnosti sa nekom drugom reprezentacijom (u ovom slučaju, to je sličnost sa originalnim iskazom u polaznom jeziku, tj. engleskom).

Već na osnovu ekscerpata 1, 1a, 2 i 2a, može da se izvede zaključak da stimulans jezika-recipijenta jeste direktni prevod ako i samo ako stvara pretpostavku o potpunoj interpretativnoj sličnosti sa originalom na izvornom jeziku. Svakako, kao što se to naglašava, pretpostavka o potpunoj sličnost kod direktnog prevoda ne garantuje njegov uspeh (Gutt, 1989: 91), već postavlja uslove za njegov prevod. Drugim rečima, pretpostavka o potpunoj sličnosti određuje da li će direktni prevod biti uspešan. Preciznije, direktan prevod će biti uspešan, ako i samo ako, prenosi interpretaciju originala kada se interpretira u pogledu originalnog konteksta (Gutt, 1989: 91).

Pogledaćemo sledeće ekscerpte iz našeg korpusa.

\section{Ekscerpt 3.}

The momentum-transfer collision cross section resulting from the charge transfer is $P_{t}=\pi b_{c}{ }^{2}$ where $b_{c}$ is the critical impact parameter for charge transfer and is related to $r_{c}$ by $\left(\frac{b_{c}}{r_{c}}\right)^{2}=1+\frac{\phi_{c}}{E}$.

\section{Ekscerpt 3a.}

Sudarni presek za prenos količine kretanja kao rezultat prenosa naelektrisanja dat je izrazom $P_{t}=\pi b_{c}^{2}$ gde je $b_{c}$ kritični sudarni parametar za prenos naelektrisanja koji je sa $r_{c}$ vezan relacijom $\left(\frac{b_{c}}{r_{c}}\right)^{2}=1+\frac{\phi_{c}}{E}$. 
Култура и/или наука

Ako pomno analiziramo ekscerpt 3 i njegov prevod na srpski jezik (tj. ekscerpt 3a), vidimo na delu deskriptivnu i interpretativnu upotrebu jezika par excellence u Sperber-Vilsonovskom smislu. Kao što vidimo engleski original u kome stoji samo kopula, odnosno oblik glagola to be (tj. is) u srpskom prevodu glasi "dat je izrazom“. Isto tako, "is related to" se ne prevodi bukvalno, već „vezan relacijom“. Ova dva primera naglašavaju važnost deskriptivnog prevođenja. Isto tako, ekscerpt 3a nam ilustruje da se pretpostavke adresata moraju ispuniti čak i na štetu komunikativne intencije manifestovane u polaznom jeziku. Pošto kognitivna reprezentacija prevedenog značenja ne može da bude tačna replika kognitivne reprezentacije originalnog značenja, pogledaćemo kako se to razrešava u sledećim ekscerptima.

\section{Ekscerpt 4.}

The gas was enclosed in a small quartz bottle situated at the center of the cavity in a region of nearly uniform microwave field. A gas discharge was produced periodically by a pulsed microwave signal that was fed into one of the three fundamental modes of the cavity. The plasma was studied in the afterglow by a microwave field in a second mode.

\section{Ekscerpt 4a.}

Gas je bio zatvoren u maloj kockastoj kvarcnoj bočici postavljenoj u centar šupljine u oblast skoro uniformnog/jednoobraznog mikrotalasnog polja. Gasno pražnjenje je uspostavljano periodično pomoću impulsnog mikrotalasnog signala preko jednog od tri osnovna tipa oscilacija ove šupljine. Plazma je ispitivana u toku gašenja pomoću mikrotalasnog polja u drugom tipu oscilacija.

Ako pažljivo pogledamo ekscerpt 4a, uočićemo da prevodilac mora da pokuša da dobije ekvivalentnu reakciju recipijenata prevoda teksta tako što će interpretirati i adaptirati jedan kod u drugi kod. Na primer, „produced“ se adekvatno prevodi „uspostavljano“ (pre nego „proizvedeno“ ili pak „generisano“), a engleski original „in a second mode“ adekvatnije se prevodi uvođenjem interpretacije, pa glasi „u drugom tipu oscilacija“. Ovaj primere tekstualnog transfera sa engleskog na srpski jezik (ekscerpti 4 i 4a) pokazuju da su se prevodioci odlučili radije za deskriptivnu strategiju, uz dodavanje adekvatne naučne interpretacije. Dakle, kao što vidi- 
mo, primenom ovog teorijskog okvira na prevođenje, dolazimo do jednog tentativnog zaključka da bi ekivalentnost zapravo mogla biti važnija od tačnosti, barem u kontekstu diskursa fizike električnih gasnih pražnjenja.

\subsection{Preliminarni rezultati}

Prilikom sagledavanja primera, smatramo da je potrebno uzeti u obzir interpretativnu relaciju, originalne pretpostavke, eksplikature I kognitivnu reakciju. Ukoliko su zahtevi za relevantnošću u tekstu (intencija + demonstrativnost + kontekstualni efekti + inferencija + pretpostavke) podjedanko realizovani, prevedeni tekst zadržava interpretativnu relaciju, odnosno, iste originalne pretpostavke i eksplikature koje zahtevaju jednaku kognitivnu reakciju, ali u tipično deskriptivnom formatu. Pogledaćemo i sledeće ekscerpte iz našeg korpusa.

\section{Ekscerpt 5.}

Rather than ionization probabilities, the measured current and voltage characteristics were of major concern. A typical type of apparatus used in such studies was a parallel plate electrode structure arranged so that a beam of light could fall on the cathode.

\section{Ekscerpt 5a.}

Ona su se odnosila više na merenje strujnih i naponskih karakteristika nego na određivanje verovatnoće za jonizaciju. Standardni tip uređaja u ovim ispitivanjima bila je elektrodna struktura sa paralelnim pločama postavljenim tako da snop svetlosti može da pada na katodu.

\section{Ekscerpt 6.}

Electrons are accelerated through a uniform field to a grid with a plate directly behind the grid. A retarding potential applied between the grid and the plate enables one to measure the number of electrons that have made inelastic collisions. By varying the accelerating potential, the dependence of the number of inelastic collisions on velocity may be estimated. 
Култура и/или наука

\section{Ekscerpt 6a.}

Elektroni se ubrzavaju kroz uniformno polje prema rešetki iza koje se neposredno nalazi ravna ploča. Zakočni potencijal, priemenjen između rešetke i ploče omogućava da se meri broj elektrona koji su izvršili neelastične sudare. Menjanjem napona za ubrzanje može se odrediti broj neelastičnih sudara u funkciji od brzine.

Originalni tekst iz ekscerpta 5 i 6 modifikovan je u neznatnoj (ali primetnoj) meri u ekscerptima 5a i 6a. Polazni tekstovi ekscerpata 5 i 6 ispoljavaju ravnotežu između intencije, demonstrativnosti i informacije sadržane u njima. U skladu sa teorijom relevantnosti, može se konstatovati da je njihov cilj da postignu adekvatnu kognitivnu reakciju i kontekstualne efekte koji čine njihovu poruku relevantnom u skladu sa pretpostavkama recipijenta čiji je maternji jezik engleski. S druge strane, recipijent srpskog prevoda zahteva informativniji input (,Ona su se odnosila više na merenje strujnih i naponskih karakteristika nego na određivanje verovatnoće za jonizaciju“; "iza koje se neposredno nalazi ravna ploča“), pa kognitivni stimulansi moraju biti jači, intencije demonstrativnije (,Standardni tip uređaja u ovim ispitivanjima“; „može se odrediti broj neelastičnih sudara u funkciji od brzine“), a kontekstualni efekti moraju da ispune očekivanja recipijenta teksta prevoda.

Kao što vidimo u analiziranim ekscerptima (5-6), iako postoji balans između intencije, demonstrativnosti i informacije u njima, a cilj im je da postignu adekvatnu kognitivnu reakciju i kontekstualne efekte kako bi poruka koju prenose bila relevantna, u ekscerptima (5a-6a), koji su prevodi engleskog originala, zahteva se ipak informativniji input, pa i kognitivni stimulansi moraju biti jači, a intencije demonstrativnije. Istovremeno, zapažanja koja smo izneli za ove eskceprte mogu da se šire odnose na prevođenje diskursa električnih gasnih pražnjenja. U narednom delu iznosimo zaključne napomene.

\subsection{Zaključne napomene}

U našem istraživanju, bavili smo se prevođenjem fizike električnih gasnih pražnjenja sa engleskog na srpski primenjujući teoriju relevant- 
nosti ne prenebregavajući da prevođenje obuhvata jezik, komunikaciju i međukulturni transfer (Martinez 1998: 172), koji može da se sagleda i iz ugla kognitivnog pristupa teorije relevantnosti.

$U$ našem istraživanju primene teorije relevantnosti na prevođenje oslonili smo se na teoriju relevantnosti Sperbera i Vilsonove. Sledstveno tome, usvojivši njihove teorijske postavke, usredsredili smo se na mentalne mehanizme koji omogućavaju učesnicima u komunikaciji da obrađuju informacije na najefikasniji način uz najmanji procesualni napor. Takođe, primenili smo njihov stav da kognitvina sposobnost omogućava prepoznavanje informativnih i komunikativnih namera.

Čini se da naše istraživanje može da pokaže u odabranom teorijskom okviru teorije relevantnosti da primena teorije relevantnost može da omogući eksplicitno tretiranje jedva primetnih i suptilnih problema koji se susreću u procesu prevođenja, a za koje se u literaturi tvrdi da prevazilaze dijapazon objektivne analize.

Analizirajući primere iz korpusa tekstova fizike električnog gasnog pražnjenja, videli smo da teorija relevantnosti može da dozvoli eksplicitna objašnjenja svakog slučaja prevoda koji pretenduje da predstavlja original na polaznom jeziku, bez pribegavanja bilo kom tipološkom okviru, bilo da je u pitanju tipologija teksta, diskursa, vrste prevoda. Skloni smo da zaključimo da bi upravo ovakav moćan aparat, koji nudi teorija relevantnosti, mogao da se iskoristiti, između ostalog za obuku prevodilaca, ali i za kontrastivnu analizu prevoda.

Naše istraživanje urađeno je na teorijskim i metodološkim osnovama teorije relevantnosti, u okviru koje smo došli do zaključka da prevod koji je definisan u smislu zajedničkih komunikativnih indicija jeste koristan i omogućava eksplicitno tretiranje suptilnijih problema prevođenja koji se ponekada nalaze van opsega klasične translatološke analize. Za razliku od poimanja prevoda koje je orijentisano ka stimulansu, primenili smo prilikom prevođenja i analize produkta prevođenja pojam interpretativne upotrebe koja se, prema literaturi, smatra i indirektnim prevodom (Gutt, 1989).

Prevođenje naučnih tekstova bi moglo biti dobar primer interpretativnog prevoda gde postizanje sličnosti sa originalnom zamisli, kao i jezički, stilski i semantički plan postaju od najvišeg značaja. Na osnovu ekscerpata koje smo analizirali (ili preciznije engleskog originala i našeg 
prevoda na srpski jezik) skloni smo da zaključimo da stimulans jezika-recipijenta jeste direktni prevod izvornog jezika ako i samo ako stvara pretpostavku o potpunoj interpretativnoj sličnosti sa originalom na izvornom jezikom. I pored toga, videli smo da potpuna sličnost kod direktnog prevoda ne garantuje uspeh prevoda. Drugim rečima, pretpostavka o potpunoj sličnosti određuje u kojoj meri je direktni prevod uspešan, ako i samo ako prenosi interpretaciju originala kada se interpretira u pogledu originalnog konteksta.

Na osnovu konkretnog istraživanja sprovednog na jezičkom materijalu diskursa fizike električnih gasnih pražnjenja, pokazalo se da teorija relevantnost može da obezbedi eksplicitan okvir za objašnjenje pojava koje se generalno mogu podvesti pod širu kategoriju „prevođenja“ (Gutt 1989: 92). Kognitivni pristup teorije relevantnosti može ponuditi teoretičarima i praktičarima prevođenja osnove za poimanje izvesnih kognitivnih procesa koji se koriste ne samo za prenošenje značenja, već i intencija iz izvornog jezika u ciljni jezik.

\section{Literatura}

Alves, Fabio and José Luiz V. R. Gonçales. "A Relevance Theory approach to the investigation of inferential processes in translation." Triangulating Translation: Perspectives in Process Oriented Research, ed. Fabio Alves, 3-24. Amsterdam: John Benjamins, 2003. Print.

Brockway, Diane. "Connecteurs pragmatiques et principe de pertinence" Langages $\mathrm{N}^{\circ}$ 67, 7-22, (1982): 7-22. Print.

Carston, Robyn. "Implicature, Explicature, and Truth-Theoretic Semantics", Pragmatics: A Reader, ed. S. Davis, 31-51. New York: Oxford University Press, 1991. Print.

Carston, Robyn. "The Relationship between Generative Grammar and (Relevance-Theoretic) Pragmatics" UCL Working Papers in Linguistics 11, (1999): 21-40. Print.

Carston, Robyn. “Linguistic Meaning, Communicated Meaning and Cognitive Pragmatics" Mind \& Language Vol. 17, Nos. 1 \& 2, (2002): 127-148. Print.

Dascal, Marcelo. “Conversational Relevance” Journal of Pragmatics 1, (1977): 309-328. Print.

Dooley, Robert A."Relevance Theory and Discourse Analysis: Complementary Approaches for Translator Training", Paper presented at BT2007, Dallas, TX, 15-17 October 2007, 1-11, Dallas: BT, 2008. Print.

Đurić, Miloš D. \& Nada Krnjaić-Cekić. „Neki aspekti prevođenja naučnih i stručnih tekstova" PREVODILAC 3-4 (72), (2014): 64-80. Print. 
Đurić, Miloš D. \& Nada Krnjaić-Cekić. „Prevođenje naučnih tekstova i teorija relevantnosti“ PREVODILAC 1-2 (75), (2014): 52-65. Print.

Guillén Galve, Ignacio. "Evaluating the Appropriateness of a Translation: A Pragmatic Application of Relevance Theory", Pragmalinguistica 3-4, (1996): 27-51. Print.

Gutt, Ernst-August.“Translation and Relevance”, In: UCL Working Papers in Linguistics 1, (1989): 75-94. Print.

Kliffer, Michael \& Magda Stroińska. "Relevance Theory and Translation", Linguistica Atlantica 25, (2004): 165-172. Print.

Kostić, Jelena. Imenice nastale konverzijom u savremenom nemačkom književnom jeziku i njihovi ekvivalenti na srpskom. Beograd: Filološki fakultet, Univerzitet u Beogradu. [Neobjavljena doktorska disertacija], 2006. Print.

Kristal, Dejvid. Enciklopedijski rečnik moderne lingvistike. Beograd: NOLIT, 1988. Print. Levinson, Stephen C. Pragmatics. Cambridge: Cambridge University Press, 1983. Print.

Martínez, José Mateo. "Be Relevant (Relevance, Translation and Cross-Culture)", Revista Alicantina de Estudios Ingleses 11, (1998): 171-182. Print.

Matthews, P. H. The Concise Oxford Dictionary of Linguistics. Reissued Edition. Oxford: Oxford University Press, 2005. Print.

May, Robert. Logical Form: Its Structure and Derivation. Second Printing. Cambridge, Massachusetts: The MIT Press, 1986. Print.

Polovina, Vesna. Prilozi za kognitivnu lingvistiku. Beograd: Filološki fakultet, 1996. Print.

Prieto, Luis J. Pertinence et pratique: essai de sémiologie. Paris: Les Éditions de Minuit, 1975a. Print.

Prieto, Luis J. Études de linguistique et de sémiologie générales. Genève et Paris: Librairie Droz, 1975b. Print.

Rosales Sequeiros, Xosé. "Types and degrees of interpretive resemblance in translation" Revista Alicantina de Estudios Ingleses 14, (2001): 197-211.

Sperber, Dan and Deirdre Wilson. "Loose Talk", Proceedings of the Aristotelian Society, New Series, Vol. 86, 153-171, 1986. Print.

Sperber, Dan and Deirdre Wilson. "Précis of Relevance, Communication and Congnition", Behavioral and Brain Sciences 10, (1987): 697-754. Print.

Sperber, Dan and Deirdre Wilson. Relevance: Communication and Cognition. Oxford: Blackwell, 1995. Print.

Sperber, Dan and Deirdre Wilson."Preface”, Revista Alicantina de Estudios Ingleses 11, (1998): v-vi.

Wilson, Deirdre. "Relevance and Relevance Theory", The MIT Encyclopedia of the Cognitive Sciences, eds. Robert A. Wilson \& Frank C. Keil, 719-720. Cambridge, Massachusetts: The MIT Press, 1999. Print.

Wilson, Deirdre and Dan Sperber. "Linguistic Form and Relevance", Lingua 90 (1993): 1-25. Print.

Wilson, Deirdre and Dan Sperber.“Outline of Relevance Theory”, Links \& Letters 1, (1994): 85-106. Print.

Wilson, Deirdre and Dan Sperber. "Truthfulness and Relevance", UCL Working Papers in Linguistics 12, (2000): 215-257. Print. 
Култура и/или наука

Wilson, Deirdre and Dan Sperber. "Relevance Theory: A Tutorial", Proceedings of the Third Tokyo Conference on Psycholinguistics, ed. Yukio Otsu, 45-70. Tokyo: Hituzi Shobo, 2002a. Print.

Wilson, Deirdre and Dan Sperber. "Relevance Theory", UCL Working Papers in Linguistics 14, (2002): 249-287. 2002b. Print.

Wilson, Deirdre and Dan Sperber. "Relevance Theory", The Handbook of Pragmatics, eds. Laurence R.Horn and Gregory Ward, 607-632. Oxford: Blackwell, 2004. Print. Yus Ramos, Francisco."A decade of Relevance theory" Journal of Pragmatics, 30, (1998): 305-345. Print.

Žegarac, Vladimir. Osnovi Teorije relevantnosti. Beograd: Odsek za opštu lingvistiku, Filološki fakultet, Univerzitet u Beogradu, 2005. Print.

Miloš D. Đurić

University of Belgrade

Faculty of Electrical Engineering

Nada Krnjaić-Cekić

University of Belgrade

Faculty of Mechanical Engineering

\section{THE RELEVANCE-THEORETIC PERSPECTIVE OF TRANSLATING THE DISCOURSE OF ELECTRICAL DISCHARGES IN GASES}

\section{Summary}

Relying on the relevance-theoretic framework, we examine the hypothesis that translation might be accounted for as an instance of ostensive-inferential communication. More specifically, our analysis is based on the relevance-theoretic assumption about the role of inference in comprehension and the cognitive semantic distinction between conceptual and procedural encodings. Our hypothesis is verified in the corpora that comprise the discourse of electrical discharges of gases (translation from English into Serbian).

Since we assert that Relevance Theory provides an explicit framework that can account for translation process, we want to illustrate certain discrepancies in translation that occur due to the effects of interpretive resemblance between what is encoded and what is communicated. We analyse and explain the occurrence of interpretive resemblance when two propositional representations share their analytic and contextual 
implications in a given context, as well as our finding that the gap between what is encoded and what is communicated has pertinent consequences for translation. In addition to this, preserving the original information content requires that the explicatures and implicatures of the translated output should be the same as the explicatures and implicatures of the original. We have detected the cases when a translator chooses to encode the interpretation of what the source concept was intended to communicate. In other words, what is communicated by a concept might depart from what it encodes by means of: concept narrowing, concept loosening, echoic uses of concepts and concept widening. Additionally, the translator sometimes employs direct translation thereby involving looser degrees of faithfulness. We introduce a novel insight into this problem by applying the relevance-theoretic framework as our analytical apparatus for analysing the translation of the discourse of electrical discharge in gases from English into Serbian. On the one hand, we believe that relevance-theoretic perspective might offer translators important ingredients in order to comprehend certain cognitive processes employed to transfer meaning and intention from one language into another. On the other hand, our investigation might also contribute to SLA process analysis, particularly if the semantic component of the process of second language acquisition is considered as a unidirectional translation from L1 to L2.

Key Words: Translational Equivalents, Relevance Theory, Interpretive Resemblance, Looser Degrees of Faithfulness, English Language, Serbian Language, the Discourse of Electrical Discharges of Gases, Corpus-Based Data. 